\title{
Erratum to: The Relationship Between Maternal Serum Iron and Zinc Levels and Their Nutritional Intakes in Early Pregnancy with Gestational Diabetes
}

\author{
Samira Behboudi-Gandevani • Kolsum Safary • \\ Lida Moghaddam-Banaem • Minoor Lamyian • \\ Azita Goshtasebi • Narges Alian-Moghaddam \\ Published online: 24 August 2013 \\ (C) Springer Science+Business Media New York 2013 \\ Erratum to: Biol Trace Elem Res (2013) 154:7-13 \\ DOI 10.1007/s12011-013-9703-y
}

The original version of this article unfortunately contained mistakes in the surname and affiliation of Azita Goshtasebi and in the second affiliation of Samira Behboudi-Gandevani. These are now corrected in this article. Instead of "Azita Goshtasbi", it should read "Azita Goshtasebi", and the correct authors' affiliations are shown below.

The online version of the original article can be found at http://dx.doi.org/ 10.1007/s12011-013-9703-y.

S. Behboudi-Gandevani $\cdot$ K. Safary $\cdot$

L. Moghaddam-Banaem $(\bowtie) \cdot$ M. Lamyian $\cdot$ N. Alian-Moghaddam

Department of Midwifery and Reproductive Health, Faculty of

Medical Sciences, Tarbiat Modares University, Al-e-Ahmad

Highway, Tehran, Islamic Republic of Iran

e-mail: moghaddamb@modares.ac.ir

S. Behboudi-Gandevani

e-mail: s.behboudi@modares.ac.ir

K. Safary

e-mail: kolsum.safary@modares.ac.ir

M. Lamyian

e-mail: lamyianm@modares.ac.ir

N. Alian-Moghaddam

e-mail: aliyan@modares.ac.ir

S. Behboudi-Gandevani

Reproductive Endocrinology Research Center,

Research Institute for Endocrine Sciences,

Shahid Beheshti University of Medical Sciences,

Tehran, Islamic Republic of Iran

\section{A. Goshtasebi}

Family Health Group of Health Metrics Research Center, Iranian Institute for Health Sciences Research, ACECR, Tehran, Iran

e-mail: agoshtasebi@ihsr.ac.ir 